\title{
Identification and characterization of the fungus Dothiorella sarmentorum on necrotic shoots of declining ash in Slovakia
}

\author{
Helena Ivanová* \\ Department of Plant Pathology and Mycology, Institute of Forest Ecology of the Slovak Academy of Sciences, \\ Akademická 2, 94901 Nitra, the Slovak Republic
}

\begin{abstract}
Ivanoví, H., 2018. Identification and characterization of the fungus Dothiorella sarmentorum on necrotic shoots of declining ash in Slovakia. Folia Oecologica, 45: 53-57.

Formerly, before the current Hymenoscyphus fraxineus epidemic, symptomatic ash twigs were habitually colonized by fungi occurring occasionally in the early stages of ash diseases. Some of these fungi are endophytes or facultative parasites. The segments of diseased shoots of the studied trees were collected from a seed orchard situated in southwest Slovakia. The frequently isolated fungus Dothiorella sarmentorum was identified microscopically and characterized with the aid of morphological keys. The disease symptoms comprise wood cankers, bud necrosis, and shoot and branch dieback displayed through bleached, necrotic or discoloured canes in infected trees. Despite the Dothiorella species has not yet been recognized to have significant economic consequences, the cumulative effects of various stressful biotic and abiotic factors may induce disorder and decline of ash trees in Slovakia.
\end{abstract}

\section{Keywords}

Fraxinus angustifolia, Fraxinus excelsior, fungus, morphological characteristics

\section{Introduction}

Fraxinus angustifolia Vahl. is a species of Fraxinus native to central and southern Europe, northwest Africa and southwest Asia. Fraxinus excelsior L. is the most widely distributed native ash species in Europe. Unlike many other broadleaved tree species, ash trees are less susceptible to large-area attacks by dangerous pests and pathogens (PAutasso et al., 2013). Recently, the situation has been changed. Large-scale dieback of $F$. excelsior and $F$. angustifolia has been detected and found incrasing in many European countries (BAKYs et al., 2009), including Slovakia where the pathogen - Hymenoscyphus fraxineus has probably been introduced from East Asia and the disease emerged in 2004 (KunCA et al., 2011). The subseguent epidemic is spreading across the entire native distribution range of the host trees.

*Corresponding author: e-mail: helena.ivanova@ife.sk
Although $H$. fraxineus is considered to be the main cause of ash trees dieback, this damage is associated with many other fungal genera colonizing ash shoots and branches (Kowalski and CzeKaJ, 2010; Kowalski et al., 2016). The fungi detected after isolation from the initial necrotic lesions on ash leaves and branches represent taxa with different heterotrophy: parasites prefering to colonize living plant tissues, saprophytes feeding on dead or decaying substrates and endophytes. The species diversity of fungi colonising damaged branches and leaves of ashes in various stand types in Slovakia was studied by PAsTiRČÁKová et al. (2018).

In the recent years, except this disease, characteristic symptoms of branch canker and dieback have been observed in a clonal seed orchard situated in southwest Slovakia. The symptoms of this disease represent wood cankers, shoot and branch dieback, bleached, necrotic

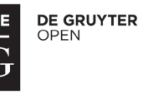


or discoloured canes, bud necrosis and a characteristic wedgeshaped lesion in the trunk of the infected trees. Among the specific canker-causing agents, Dothiorella sp. are reported as important limiting factors (DEIDA, 2014). Dothiorella is currently represented by four species, namely D. pyrenophora Sacc., D. sarmentorum A.J.L. Phillips, Alves \& Luque, D. iberica A.J.L. Phillips, Luque \& Alves and $D$. viticola A.J.L. Phillips \& Luque.

The goal of this study was to identify and characterize the fungus $D$. sarmentorum colonizing the symptomatic ash shoots. Mycological analysis was performed by classical isolation of the most frequently isolated fungus from ash necrotic tissues from twigs. The analysis confirmed Dothiorella sarmentorum (Fr.). The genus encompassed a wide range of morphologies from thin-walled, hyaline, aseptate conidia to thick-walled, brown, 1-septate conidia (PhILliPs et al., 2005). Initial necrotic lesions and characteristic symptoms of branch canker occurred either on young or on stressed and weakened trees. Dieback is a condition where a tree begins to die from the twig-tips as a result of a disease or an unfavourable environment such as a chronic water stress.

\section{Material and methods}

The study material was collected from the Trstice sites (GPS: $48^{\circ} 00^{\prime} 50.6^{\prime} \mathrm{N}, 17^{\circ} 48^{\prime} 18.4^{\prime \prime} \mathrm{E}$ ), a clonal seed orchard situated in southwest Slovakia. The average annual temperature at the site is $10{ }^{\circ} \mathrm{C}$, the average annual precipitation is from 550 to $600 \mathrm{~mm}$ and the average altitude is $111 \mathrm{~m}$.

The inspection material consisted of segments $(40 \mathrm{~cm}$ long sections) of diseased shoots displaying visible external initial necrotic lesions. There were sampled all 50 living ash trees at the site. The sampoling was carried out in 2017. The fungal isolates from the initial necrotic lesions were obtained from collections of samples $F$. angustifolia and $F$. excelsior. To study the growth rates of $D$. sarmentorum, the shoots segments were surface-sterilized by soaking for $10 \mathrm{~min}$. in a solution of sodium hypochlorite, and then they were transferred onto PDA plates and incubated at $24{ }^{\circ} \mathrm{C}$ at $45 \%$ humidity in darkness in a versatile environmental test chamber Sanyo MLR-351H. The plates were inspected daily. The isolates were assessed morphologically and classified into morphological similarity groups. The species were identified on the basis of macroscopic characteristics such as pigmentations and growth rates on PDA plates, as well as their microscopic features including size of ascomata, asci, presence of conidia, type of conidiogenous cells. The spores were scanned with an Olympus E410 camera and measured using Quick Micro Photo (version 2.1) software.

The statistic characteristics for expressing microscopic traits are given as the mean value (bold letters), the mean value plus/minus standard deviation, and they have been calculated 30 measurements. The values in parentheses represent the measured minimum or maximum values. The experiments and morphometric measurements were carried out with implementing a widely accepted methodology (IVANOvá and BERnADOvičové, 2010; IVANOvá, 2015). The identification was performed using mycological (Phillips et al., 2013) or morphological studies (PHILLIPS et al., 2005; PITT et al., 2013).

\section{Results}

Some fungi are associated only or mainly with the Fraxinus species, while the other may have a very wide host range. A reperesentative of this second type is the fungus Dothiorella sarmentorum, (syn. Diplodia sarmentorum (Fr.) Fries, Deuteromycetes, Coelomycetes, Botryosphaeriaceae), an anamorphic state represented as Botryosphaeria teleomorph identified in initial necrotic lesions on ash.

Also D. sarmentorum has been isolated from the vascular tissue of ash sprouts (Fig. 1a). Therefore, dormant cuttings may provide a corridors for this fungus. The cultures were collected from samples of $F$. angustifolia and $F$. excelsior (Figs. 1b, c). Quicker growth rates of fungal mycelium was observed for $F$. excelsior. On the artificial medium, the mycelium formed filamentous colonies. Initially it was leaden appressed, subsequently forming small white cottonies, within 7 days. Later, the mycelium turned dark and became smoke-grey to olivaceous grey at the surface, starting from the centre. The mycelium immersed, consisting of septate, branched, brown, finely verruculose hyphae, $3.5-4.5 \mu \mathrm{m}$ in size. The growth of ash isolates causing branch cankers showed that this species were able to grow in a wide range of temperatures (22-25 ${ }^{\circ} \mathrm{C}$ ) with an optimum of $25{ }^{\circ} \mathrm{C}$. The fungus formed dark brown to black globose ascomata, 350-400 $\mu \mathrm{m}$ diam., ostiolate, ostiole central, circular and papillate (Fig. 1d). The asci were clavate, bitunicate (Fig. 1e). Conidiomata readily formed from the middle of colonies within 7-10 days were pycnidial, solitary, globose, dark brown to black, immersed in the medium, thick-walled, up to 400 $\mu \mathrm{m}$ wide with single ostiole. Conidiophores were hyaline, smooth, rarely branched. Conidiogenous layer with developing conidia was thick, composed of dark brown 5-6 cell layers. Conidiogenous cells (Fig. 1f) were cylindrical to fusiform, hyaline, thin walled, smooth and giving rise to periclinal thickenings. Dark, oval to ovoid, often pigmented ellipsoid conidia (diplodia like) were (21-)22.3624.43-26.51(-27) × (7-)7.52-9.33-11.15(-12) $\mu \mathrm{m}$ in size (Table 1), hyaline, later brown, thick-walled, 1-septate prior to release from conidiogenous cells, occasionally slightly constricted at the septum with a broadly rounded apex and truncate base (Figs 1g, h).

\section{Discussion}

The family Botryosphaeriaceae include important stressassociated pathogens infecting a wide variety of woodyplant species. These fungi play an increasingly important role in tree diseases, in context of the predicted temperature increase and drought stress gradation associated with the global climate change (DESPREZ-Loustau et al., 2006; SLIPPERS and WINGFIELD, 2007). 


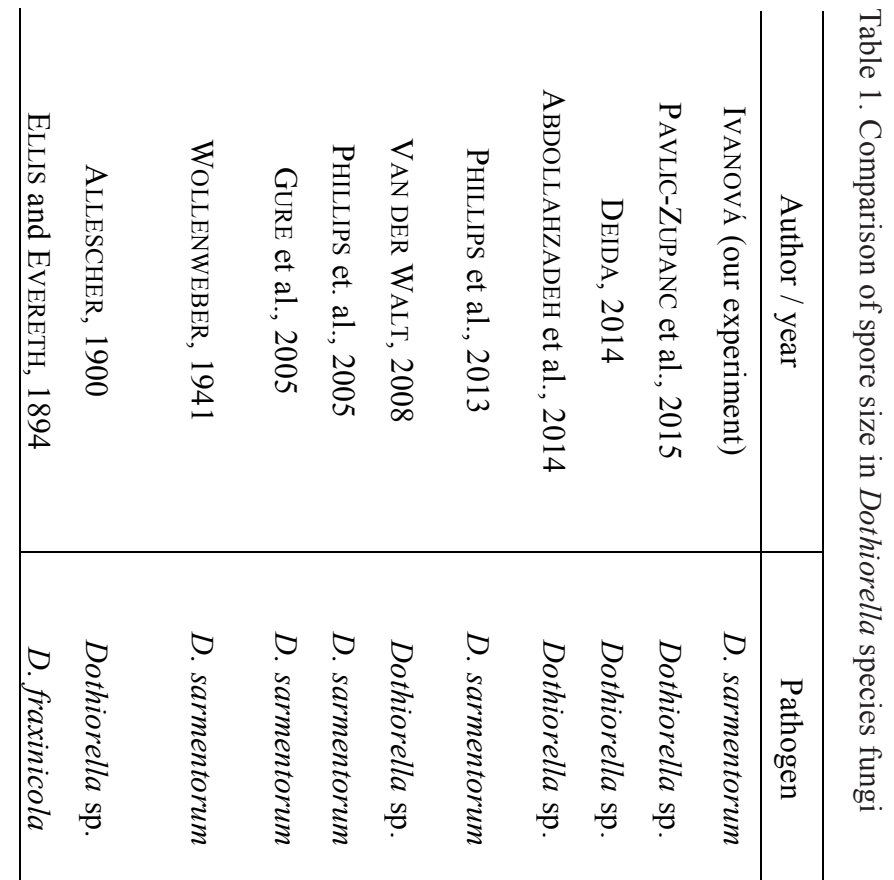

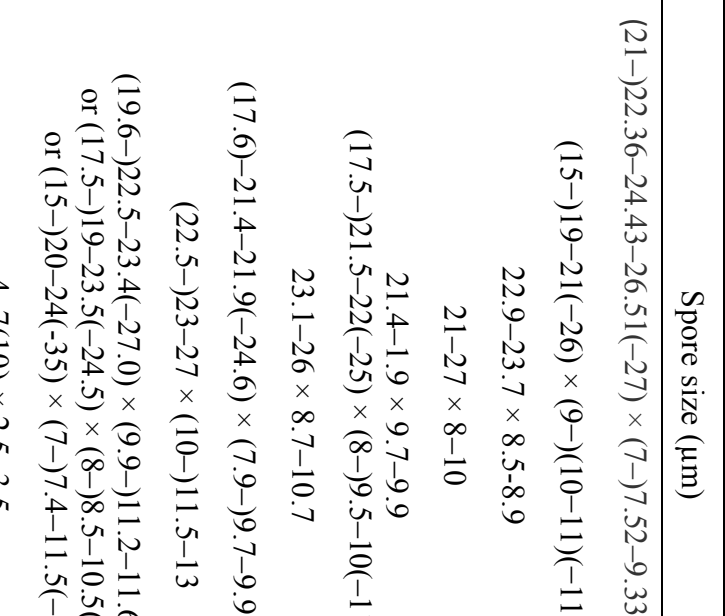

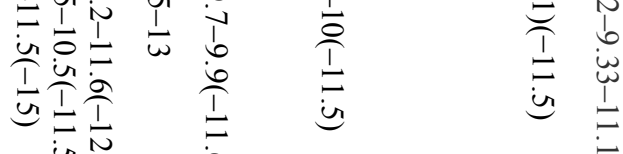

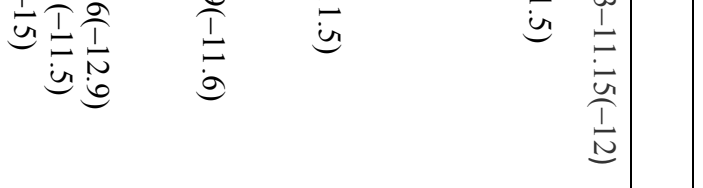

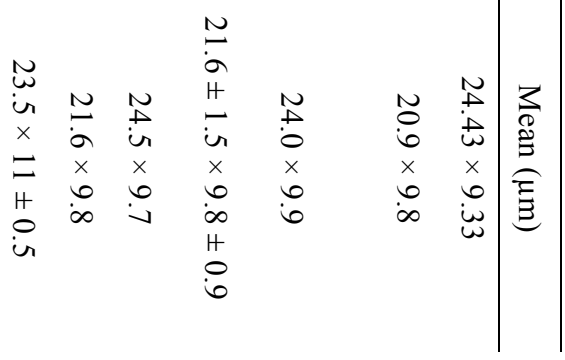




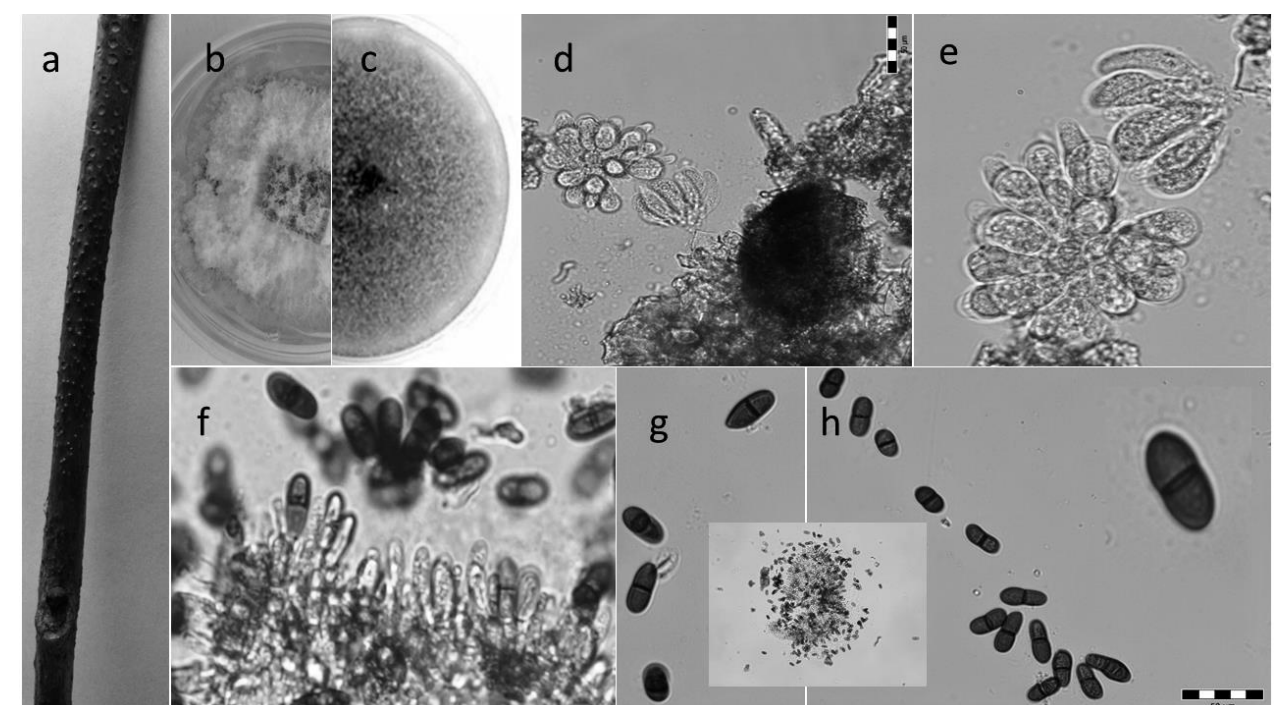

Fig. 1. Dothiorella sarmentorum: a - branch of ash with necrotic lesions; b, c - colonies of white, later olivaceous grey mycelia after 7 (b) and 21 days (c) of incubation on PDA; $d$ - dark brown globose ascomata; e - clavate, bitunicate asci; $\mathrm{f}$ - conidiogenous cells; $\mathrm{g}, \mathrm{h}$ - dark, ovoid, diplodia-like conidia. Scale bars: $\mathrm{d}, \mathrm{h}=50 \mu \mathrm{m}$.

According to Urbes-TorRes (2011), the fungus produces pycnidia that, when mature, exude conidia in gelatinous matrices forming cirri. These conidia are splashborne dispersed during rainfall, arriving to susceptible pruning wounds. This species is distributed across a wide range of climates. Parts of Slovakia have suitable climatic conditions for the establishment and spreading of this species. Propagation and distribution of infected material will promote spreading this fungus within Slovakia. The wide temperature range at which these fungi can grow suggests that the species of Botryosphaeriaceae are able to grow under a range of different very varied environmental conditions (PHILlips et al., 2013). The optimum temperature for growth of isolates for fungi Dothiorella spp. and Diplodia spp. is close to $25^{\circ} \mathrm{C}$.

These results agree with those reported for the isolates Diplodia (Moral et al., 2010), Dothiorella sp. and D. sarmentorum (PAVlic-ZuPANC et al., 2015). The conidia of fungus $D$. sarmentorum in our experiment become pigmented while still attached to the conidiogenous cell. In lenght and width, they were most similar to $D$. sarmentorum, but slightly shorter than conidia of $D$. fraxinicola (Ellis and Evereth, 1895) with 18-30 × 6-7 $\mu \mathrm{m}$ in size and than conidia of Dothiorella sp. with 4-7 (10) $\times$ 2.5-3.5 $\mu \mathrm{m}$ in size (Allescher, 1900). Wollenweber (1941) reported a wide range of dimensions for the conidia (Table 1). Some species in Dothiorella are separated by minor differences in conidium dimensions. It is therefore possible that some of Wollenweber's synonyms are in fact distinct species. Species of Dothiorella are morphologically most similar to those of Diplodia (DENMAN et al., 2000) and they have anamorphs characterized by dark, ovoid, often pigmented conidia. However Dothiorella conidia turn brown and 1-septate while still in the pycnidium and sometimes even when they are still attached to the co- nidiogenous cells, conidia of Diplodia typically become dark and septate only after discharge from the pycnidium (PhILlips et al., 2005). Diplodia, Lasiodiplodia and Dothiorella all are morphologically similar members of the Botryosphaeriaceae. These genera have conidia that are similar in size and shape, initially hyaline, but becoming pigmented with age (DE WeT et al., 2009). According to Phillips et al. (2005) Dothiorella differs from Diplodia in morphological and molecular characteristics. Their conidia become brown and septate at an early stage, even before dehiscenesce from the conidiogenous cell, whereas conidia in Diplodia are hyaline and become dark and septate only with age.

\section{Conclusion}

The work presents the results considering occurrence of the fungus Dothiorella sarmentorum colonizing twigs of Fraxinus excelsior and F. angustifolia are presented. Characteristic symptoms - necrotic lesions of branch canker occured on young or on stressed and weakened ash trees. Mycological analysis was performed by classical isolation of the fungus from ash necrotic tissue from twigs. The analysis confirmed Dothiorella sarmentorum (Fr.). Spore size and shape are important taxonomic features and valuable criteria for distinguishing the species, although there is a considerable intraspecific variation. To characterize the variability of the $D$. sarmentorum spore size, we used statistical evaluation, resulting in a value: (21-)22.36-24.43$26.51(-27) \times(7-) 7.52-9.33-11.15(-12) \mu \mathrm{m}$. The spores of D. sarmentorum were Diplodia like, hyaline, later dark brown, oval to ovoid or ellipsoid, often pigmented, thick-walled, one septate, with a broadly rounded apex and truncate base slightly constricted at the septum. In 
context of a rich diversity of fungi on ashes in the orchard site studied, the presented fungus $D$. sarmentorum is the one with the lowest recorded economic consequences.

\section{Acknowledgements}

This work was supported by the Scientific Grant Agency of the Ministry of Education and the Slovak Academy of Sciences under the contract VEGA 2/0062/18.

\section{References}

AbdollahZadeh, J., JaVadi, A., Zare, R., Phillips, A.J.L., 2014. A phylogenetic study of Dothiorella and Spencermartinsia species associated with woody plants in Iran, New Zealand, Portugal and Spain. Persoonia, 32: $1-12$.

Allescher, A., 1900. Fungi imperfecti. In Rabenhorst's Kryptogamen-Flora von Deutschland, Österreich und der Schweiz. 2. Aufl. Leipzig: Kummer, Band 1, Abteilung 6, p. 1-830.

Bakys, R., Vasaitis, R., Barklund, P., Thomsen, I.M., Stenlid, J., 2009. Occurrence and pathogenicity of fungi in necrotic and non-symptomatic shoots of declining common ash (Fraxinus excelsior) in Sweden. European Journal of Forest Research, 128: 51-60.

DEIDA, A., 2014. Botryospaheriaceae species associated with cankers and dieback of grapevine and other woody hosts in agricultural and foresty ecosystem. $\mathrm{PhD}$ thesis. Sassari: University of Sassari. 147 p.

Denman, S., Crous, P.W., Taylor, J.E., Kang, J.C., PasCOE, I., Wingfield, M.J., 2000. An overview of the taxonomic history of Botryosphaeria, and a re-evaluation of this anamorphs based on morphology and ITS rDNA phylogeny. Studies in Mycology, 45: 129-140.

Desprez-Loustau, M.L., Marcais, B., NageleiSEN, L.M., Piou, D., VAnNini A., 2006. Interactive effects of drought and pathogens in forest trees. Annals of Forest Science, 63: 597-612.

De Wet, J., Slippers, B., Preising, O., Wingfield, B., TsoPElAS, P., Wingfield, M.J., 2009. Molecular and morphological characterization of Dothiorella casuarini sp. nov. and other Botryosphaeriaceae with diplodia-like conidia. Mycologia, 101 (4): 503-511.

Ellis, J.B., Evereth, B.M., 1895. New species of fungi from various localities. In Proceedings of the Academy of Natural Sciences of Philadelphia, 47: 413-441.

Gure, A., SlipPers, B., Stenlid, J., 2005. Seed-borne Botryosphaeria spp. from native Prunus and Podocarpus trees in Ethiopia, with a description of the anamorph Diplodia rosulata sp. nov. Mycological Reserach, 109 (9): 1005-1014.

IvANOví, H., 2015. Fungi associated with a decline of Pinus nigra in urban greenery. Acta Fytotechnica et Zootechnica, 18 (2): 36-42.

Ivanová, H., BERNADOvičové, S., 2010. Species diversity of microscopic fungi on Austrian pines growing in urban greenery of Nitra town. Folia Oecologica, 37: 168-180.

Kowalski, T., Czekau, A., 2010. Disease symptoms and fungi on dying ash trees (Fraxinus excelsior L.) in Staszów forest district stands. Leśne Prace Badawcze, 71 (4): 357-368.

Kowalski, T., Kraj, W., Bernarz, B., 2016. Fungi on stems and twigs in initial and advanced stages of dieback of Europaean ash (Fraxinus excelsior) in Poland. European Journal of Forest Research, 135 (3): 565-579.

Kunca, A., Leontovyč, R., Zúbrik, M., GubKa, A., 2011. Bark beetle outbreak on weakened ash trees and applied control measures. Bulletin OEPP/EPPO Bulletin, 41: 11-13.

Moral, J., Muñoz-Díez, C., González, N., Trapero, A., Michailides, T.J., 2010. Characterization and pathogenicity of Botryosphaeriaceae species collected from olive and other hosts in Spain and California. Phytopathology, 100 (12): 1340-1351.

Pastirčáková, K., Ivanová, H., PAStirčÁK, M., 2018. Species diversity of fungi on damaged branches and leaves of ashes (Fraxinus sp.) in different types of stands in Slovakia. Central European Forestry Journal, 64: 127-133.

Pautasso, M., Aas, G., Queloz, V., Holdenrieder, O., 2013. European ash (Fraxinus excelsior) dieback: a conservation biology challenge. Biological Conservation, 158: 37-49.

Pavlic-Zupanci, D., PišKur, B., SlipPers, B., Wingfield, M.J., JuRC, D., 2015. Molecular and morphological characterization of Dothiorella species associated with dieback of Ostrya carpinifolia in Slovenia and Italy. Phytopathologia Mediterranea, 54 (2): 222-231.

PITt, W.M., Úrbez-Torres, J.R., Troulllas, F.P., 2013. Dothiorella vidmadera, a novel species from grapevines in Australia and notes on Spencermartinsia. Fungal Diversity, 61: 209-219.

Phillips, A.J.L., Alves, A., Correia, A., Lugue, J., 2005. Two new species of Botryosphaeria with brown, 1-septate ascospores and Dothiorella anamorphs. $M y$ cologia, 97: 513-529.

Phillips, A.J.L., Alves, A., Abdollahzadeh, J., SlipPers, B., Wingfield, M.J, Groenewald, J.Z.,' Crous, P.W., 2013. The Botryosphaeriaceae: genera and species known from culture. Studies in Mycology, 76 (1): 51-167.

SliPPERS, B., M. J. WingField, M.J., 2007. Botryosphaeriaceae as endophytes and latent pathogens of woody plants: diversity, ecology and impact. Fungal Biology Reviews, 21: 90-106.

Úrbez-Torres, J.R., 2011. The status of Botryosphaeriaceae species infecting grapevines. Phytopathologia Mediterranea, 50: 5-45.

VAN DER WALT, F.J.J., 2008. Botryosphaeriace associated with Acacia species in southern Africa with special reference to A. melifera. MSc thesis. South Africa: University of Pretoria. $198 \mathrm{p}$.

Wollenweber, H., 1941. Diplodia sarmentorum Fries und ihre Verbreitung. Zentralblatt fur Bakteriologie, Parasitenkunde, Infektionskrankheiten und Hygiene, 103 (2): 347-357.

Received October 12, 2017 Accepted February 2, 2018 